\title{
Effective clay material enriched with thiol groups for Zn(II) removal from aqueous media: A statistical approach based on response surface methodology
}

\author{
Ümit Ecer, ${ }^{1}$ Şakir Y1lmaz, ${ }^{1, *}$ Tekin Şahan ${ }^{1}$
}

Van Yuzuncu Yil University, Faculty of Engineering, Department of Chemical Engineering, 65080 Van Turkey, sakiryilmaz@yyu.edu.tr, ORCID: 0000-0001-9797-0959

\section{A B S T R A C T}

In the present work, the removal of $\mathrm{Zn}(\mathrm{II})$ ions from aquatic environments onto 3mercaptopropyl trimethoxysilane modified kaolin (MK) was investigated in a batch system. Moreover, the optimization and effects of independent parameters such as $\mathrm{pH}$, initial $\mathrm{Zn}$ (II) concentration $\left(\mathrm{C}_{0}, \mathrm{mg} / \mathrm{L}\right)$ and contact time (min) on the uptake of $\mathrm{Zn}(\mathrm{II})$ onto MK were examined by response surface methodology (RSM). Central composite design (CCD) in RSM, the most popular statistical technique, was successfully applied to optimize and model the selected parameters ( $\mathrm{pH}, \mathrm{C}_{0}$, contact time) for $\mathrm{Zn}(\mathrm{II}) \%$ adsorption onto MK. The number of experiments based on CDD was 20, a total of 20 sets which included fourteen factorial points and six center points were performed to obtain the maximum $\mathrm{Zn}$ (II) uptake from aqueous solutions. The optimum points obtained from CCD were 6.39, $50.09 \mathrm{mg} / \mathrm{L}$ and $76.10 \mathrm{~min}$ for $\mathrm{pH}, \mathrm{C}_{\mathrm{o}}$, and contact time, in their given order. In these optimal conditions, the maximum removal percentage was found to be $86.19 \%$. The results indicated that the removal yield of $\mathrm{Zn}$ (II) from aqueous media onto MK was successfully performed by CCD in RSM. It can be concluded that $\mathrm{MK}$ is also a promising material for the uptake of other heavy metals similar to Zn.

\section{ARTICLE INFO}

Research article

Received: 25.09.2020

Accepted: 17.12.2020

Keywords:

Adsorption,

kaolin,

response surface

methodology,

thiol,

zinc

*Corresponding author

\section{Introduction}

Rapid industrialization and growing population have become critical environmental issues due to the increasing contamination of water resources by pollutants such as heavy metal ions [1]. Environmental pollution is one of the most significant issues for many forms of life [2], because the presence of heavy metals in aquatic media is a major concern owing to their toxic effects on all living organisms [3]. Zinc, a heavy metal, is found in various industrial effluents including those from galvanizing plants, leather industries, electroplating, paper mills, and mining [3, 4]. These toxic effluents in aqueous environments cause serious health risks like skin irritation, stomach cramps, anemia, cancer, nausea, brain damage, and accumulative poisoning [4]. Therefore, it becomes mandatory to remove $\mathrm{Zn}(\mathrm{II})$ ions as a toxic metal from aqueous environments.

Several traditional approaches were reported to eliminate heavy metal ions from aquatic environments like reverse osmosis, chemical precipitation, electrochemical treatment, membrane processes, and adsorption. These treatment procedures have some disadvantages because of economic constraints, sludge disposal, and inefficiency at low heavy metal ion concentrations [5]. Among these techniques, the adsorption approach is considered more economic and effective for uptake of contaminants from wastewater owing to high efficiency, low cost, and simplicity of operation [6]. The effectiveness of the adsorption process depends on cost, nature, and regeneration of the selected adsorbent. Hence, adsorbents with low-cost and abundant in nature such as clay minerals have attracted attention in the field of adsorption process. These materials, however, have some drawbacks such as low removal rate, high regeneration cost, low surface area and long adsorption equilibrium time [4, 5, 7]. Recently, surface-functionalized natural clay minerals gained increasing attention via to enhance the adsorption capacity the adsorption process [8]. For example, Olu-Owolabi and Unuabonah [9] reported that sulfur and phosphorus modified bentonite had enhanced removal capability for $\mathrm{Zn}(\mathrm{II})$ adsorption after surface modification in comparison with raw bentonite. Jemima et al. [10] evaluated the removal performance for Cr(VI) by modifying montmorillonite clay with various cationic surfactants. They reported that modified- 
montmorillonite materials had excellent adsorption performance compared to unmodified clay.

Conventional methods require extra experiments, extra time, and large doses of materials because only one independent parameter affecting the adsorption is changed while the other parameters are kept at fixed points during these processes. These methods are therefore disadvantageous. Statistical programs such as response surface methodology (RSM) are promising to overcome these problems $[11,12]$.

The objective of this study was to model and optimize the removal of $\mathrm{Zn}(\mathrm{II})$ ions onto 3-mercaptopropyl trimethoxysilane-modified kaolin (MK) by using response surface methodology (RSM). A central composite design (CCD) was used to determine optimal conditions for the independent parameters, such as $\mathrm{pH}$, initial $\mathrm{Zn}$ (II) concentration, and contact time, that affect the removal of $\mathrm{Zn}(\mathrm{II})$ onto MK from aqueous environments.

\section{Materials and methods}

Clay minerals used as adsorbent in the current work were acquired from the JSC Glukhovetsky Kaolin Plant located in Ukraine. Prior to utilization as adsorbent, the obtained materials were washed with ultra-pure water and dried in a drying-oven at $120{ }^{\circ} \mathrm{C}$ for $18 \mathrm{~h}$. The dried samples were then ground into fine powder using a mill and passed through a sieve. Finally, the prepared samples were modified based on the previously reported method in the literature [13].

Zn(II) stock solution (500 mg/L) was prepared by dissolving the calculated metal salt of $\mathrm{Zn}\left(\mathrm{NO}_{3}\right)_{2} \cdot 6 \mathrm{H}_{2} \mathrm{O}$ in $500 \mathrm{~mL}$ of ultra-pure water. The desired concentrations were prepared by using dilutions of the stock solution.

All tests were carried out by adding $0.25 \mathrm{~g}$ amount of $\mathrm{MK}$ in $50 \mathrm{~mL}$ to the heavy metal ion solution with desired $\mathrm{pH}$, initial $\mathrm{Zn}(\mathrm{II})$ ions concentration $\left(\mathrm{C}_{0}, \mathrm{mg} / \mathrm{L}\right)$, and contact time (min). All tests for the three selected independent parameters of $\mathrm{pH}$, $\mathrm{C}_{0}$, and contact time were generated by CCD in RSM by taking fixed mixing rate of $700 \mathrm{rpm}$ and room temperature. After that, the suspension of the adsorbent was separated by a centrifuge at $9000 \mathrm{rpm}$ for $15 \mathrm{~min}$. The obtained supernatant was analyzed by an atomic absorption spectrophotometer (AAS, Thermo Scientific iCE 3000 SERIES, USA). The removal percentage of $\mathrm{Zn}(\mathrm{II})$ with adsorption onto MK was determined by the following equation;

$$
Z n(I I) \% \text { Adsorption }=\frac{\left(C_{o}-C_{e}\right)}{C_{o}} \times 100
$$

where $C_{o}$ and $C_{e}(\mathrm{mg} / \mathrm{L})$ are the initial and equilibrium $\mathrm{Zn}(\mathrm{II})$ concentration in the solution $(\mathrm{mg} / \mathrm{L})$, respectively.

CCD in RSM is the most effective program and was applied to optimize the selected independent parameters. The levels of the selected parameters were coded as +1 (upper), 0 (central), and -1 (bottom), as presented in Table 1. A second-order polynomial model typifying system behavior is represented as follows:

$$
\hat{y}_{n}=\beta_{o}+\sum_{i=1}^{3} \beta_{i} x_{i}+\sum_{i=1}^{3} \beta_{i i} x_{i}^{2}+\sum_{i=1}^{3} \sum_{j=i+1}^{3} \beta_{i j} x_{i} x_{j}
$$

where $\hat{y}_{n}$ is the predicted response (Zn(II)\% adsorption), $X_{i}$ ( $i$ $=1-3)$ are the independent parameters being studied, $\beta_{0}, \beta_{i}$, $\beta_{i i}$, and $\beta_{i j}$ are the intercept, the linear, the quadratic, and the interactive effects, respectively.

\section{Results and discussion}

\subsection{Characterization of adsorbent}

MK characterization was already reported in our previous study [13]. Based on the obtained results, transform infrared (FTIR) spectroscopy analysis results indicated that the peak representing $-\mathrm{SH}$ stretching vibration was present at 2550$2600 \mathrm{~cm}^{-1}$, which was not observed in unmodified kaolin. Furthermore, the characteristic peak observed at $2931 \mathrm{~cm}^{-1}$ was due to methoxy groups $\left(-\mathrm{OCH}_{3}\right)$ in MK. From energydispersive $\mathrm{X}$-ray spectroscopy (EDX) results, the sulfur peak was different from raw kaolin, indicating that the surface of the kaolin was successfully covered with $-\mathrm{SH}$ groups. X-ray diffraction (XRD) analyses showed that the diffraction signal intensity was diminished, relating to the formation of silanol groups on the kaolin surface and methoxy groups.

\subsection{Experimental and statistical analysis}

The CCD approach in RSM was successfully performed to evaluate the optimal process points for $\mathrm{Zn}(\mathrm{II})$ onto $\mathrm{MK}$. The threeindependent parameters $\left(\mathrm{pH}, \mathrm{C}_{0}\right.$, and contact time) were selected to maximize $\mathrm{Zn}$ (II) adsorption onto MK. These parameters were segregated into three levels with a coded value $(-1,0,+1)$. From CCD, 20 experimental runs were carried out as given in Table 1 . These tests designated by CCD were performed against percentage removal of $\mathrm{Zn}(\mathrm{II})$ for each independent parameter. The second-order model equation obtained from CCD which indicates the relationship between $\mathrm{Zn}(\mathrm{II})$ removal efficiency and independent variables is given in the following:

\footnotetext{
$\mathrm{Zn} \%$ adsorption $=-47.54189+27.40655[\mathrm{pH}]+1.48875\left[\mathrm{C}_{0}\right]+0.48135[$ Contact time $]$

$+7.08333 \mathrm{E}-003[\mathrm{pH}]\left[\mathrm{C}_{o}\right]-0.018409[\mathrm{pH}][$ Contact time $]+3.00606 \mathrm{E}-003\left[\mathrm{C}_{o}\right][$ Contact time $]$ (4 $-2.45621[\mathrm{pH}]^{2}-0.015857\left[\mathrm{C}_{o}\right]^{2}-2.98873 \mathrm{E}-003[$ Contact time]
}

Statistical analysis was used to evaluate whether the adsorption process was significant. For this purpose, the importance of the suggested quadratic model for the removal of $\mathrm{Zn}$ (II) onto MK was determined by the analysis of variance (ANOVA). The ANOVA results (Table 2) showed that the suggested model for the removal percentage of $\mathrm{Zn}(\mathrm{II})$ ions onto MK was dependent on the selected parameters. Moreover, low $p$-value $(<0.0001)$ and the determination of 
coefficient $\left(R^{2}\right)$ value of 0.96 demonstrated that the obtained model has good fit for predicting the removal percentage of $\mathrm{Zn}(\mathrm{II})$ onto MK.

Table 2 illustrates that the linear factors ( $A$ and $C$ ), the interaction of factor $(B C)$, and the quadratic of factors $\left(A^{2}, B^{2}\right.$, and $C^{2}$ ) are statistically significant model terms. However, it can be said that any independent parameter has little effect on the model equation, even if the other parameters were insignificant terms to the response.

Table 1. Uncoded and coded values of the independent parameters and CCD matrix corresponding to response values.

\begin{tabular}{|c|c|c|c|c|}
\hline \multirow{2}{*}{\multicolumn{2}{|c|}{ Parameters }} & \multicolumn{3}{|c|}{ Uncoded and coded values } \\
\hline & & -1 & 0 & +1 \\
\hline \multirow{3}{*}{\multicolumn{2}{|c|}{$\begin{array}{l}\mathrm{pH}(\mathrm{A}) \\
\mathrm{Co}_{0}(\mathrm{mg} / \mathrm{L}, \mathrm{B}) \\
\text { Contact time } \\
(\mathrm{min}, \mathrm{C})\end{array}$}} & 2 & 5 & 8 \\
\hline & & 20 & 50 & 80 \\
\hline & & 10 & 65 & 120 \\
\hline Run & A & B (mg/L) & C (min.) & $\begin{array}{l}\mathrm{Zn}(\mathrm{II}) \% \\
\text { removal }\end{array}$ \\
\hline 1 & $5(0)$ & $50(0)$ & $65(0)$ & 84.50 \\
\hline 2 & $5(0)$ & $50(0)$ & $65(0)$ & 84.41 \\
\hline 3 & $8(+1)$ & $50(0)$ & $65(0)$ & 72.12 \\
\hline 4 & $8(+1)$ & $80(+1)$ & $10(-1)$ & 41.93 \\
\hline 5 & $5(0)$ & $50(0)$ & $65(0)$ & 83.95 \\
\hline 6 & $5(0)$ & $50(0)$ & $65(0)$ & 83.88 \\
\hline 7 & $5(0)$ & $20(-1)$ & $65(0)$ & 75.53 \\
\hline 8 & $2(-1)$ & $20(-1)$ & $10(-1)$ & 22.93 \\
\hline 9 & $2(-1)$ & $50(0)$ & $65(0)$ & 66.36 \\
\hline 10 & $2(-1)$ & $20(-1)$ & $120(+1)$ & 36.74 \\
\hline 11 & $5(0)$ & $50(0)$ & $10(-1)$ & 81.86 \\
\hline 12 & $5(0)$ & $80(+1)$ & $65(0)$ & 78.62 \\
\hline 13 & $2(-1)$ & $80(+1)$ & $120(+1)$ & 57.55 \\
\hline 14 & $5(0)$ & $50(0)$ & $65(0)$ & 84.62 \\
\hline 15 & $8(+1)$ & $80(+1)$ & $120(+1)$ & 63.43 \\
\hline 16 & $5(0)$ & $50(0)$ & $65(0)$ & 84.25 \\
\hline 17 & $8(+1)$ & $20(-1)$ & $10(-1)$ & 38.41 \\
\hline 18 & $8(+1)$ & $20(-1)$ & $120(+1)$ & 45.86 \\
\hline 19 & $2(-1)$ & $80(+1)$ & $10(-1)$ & 18.11 \\
\hline 20 & $5(0)$ & $50(0)$ & $120(+1)$ & 82.75 \\
\hline
\end{tabular}

Table 2. ANOVA results.

\begin{tabular}{|c|c|c|c|c|c|}
\hline Source & $\begin{array}{c}\text { Sum of } \\
\text { squares }\end{array}$ & df & $\begin{array}{c}\text { Mean } \\
\text { square }\end{array}$ & F value & $\begin{array}{c}\text { p-value } \\
\text { (Prob > } \\
\text { F) }\end{array}$ \\
\hline $\begin{array}{l}\text { Model } \\
\text { (significant) }\end{array}$ & 9222.80 & 9 & 1024.76 & 27.19 & $\begin{array}{c}< \\
0.0001\end{array}$ \\
\hline $\mathrm{A}-\mathrm{pH}$ & 360.72 & 1 & 360.72 & 9.57 & 0.0114 \\
\hline B-Co $(\mathrm{mg} / \mathrm{L})$ & 161.36 & 1 & 161.36 & 4.28 & 0.0654 \\
\hline $\begin{array}{l}\text { C-Contact } \\
\text { time (min.) }\end{array}$ & 690.39 & 1 & 690.39 & 18.32 & 0.0016 \\
\hline $\mathrm{AB}$ & 3.25 & 1 & 3.25 & 0.086 & 0.7750 \\
\hline $\mathrm{AC}$ & 73.81 & 1 & 73.81 & 1.96 & 0.1919 \\
\hline $\mathrm{BC}$ & 196.81 & 1 & 196.81 & 5.22 & 0.0454 \\
\hline$A^{2}$ & 1343.85 & 1 & 1343.85 & 35.66 & 0.0001 \\
\hline $\mathrm{B}^{2}$ & 560.06 & 1 & 560.06 & 14.86 & 0.0032 \\
\hline $\mathrm{C}^{2}$ & 224.78 & 1 & 224.78 & 5.97 & 0.0347 \\
\hline
\end{tabular}

Adj. R2 $=0.93 \quad$ C.V. $\%=9.53 \quad$ Press $=2590.92$

Std. Dev. $=6.14 \quad$ Adeq Precision $=14.82$

The comparison of values predicted by the model vs observed for the removal percentage of $\mathrm{Zn}(\mathrm{II})$ is presented in Figure 1a. The observed data are quite close to the predicted data, indicating that the suggested model satisfactorily describes the correlation between independent parameters and adsorption of Zn(II) on MK. The normal probability plot of the residuals for $\mathrm{Zn}(\mathrm{II})$ adsorption is illustrated in Figure $1 \mathrm{~b}$. From Figure 1b, the errors are normally distributed, indicating that the obtained quadratic model could perfectly estimate the experimental values.
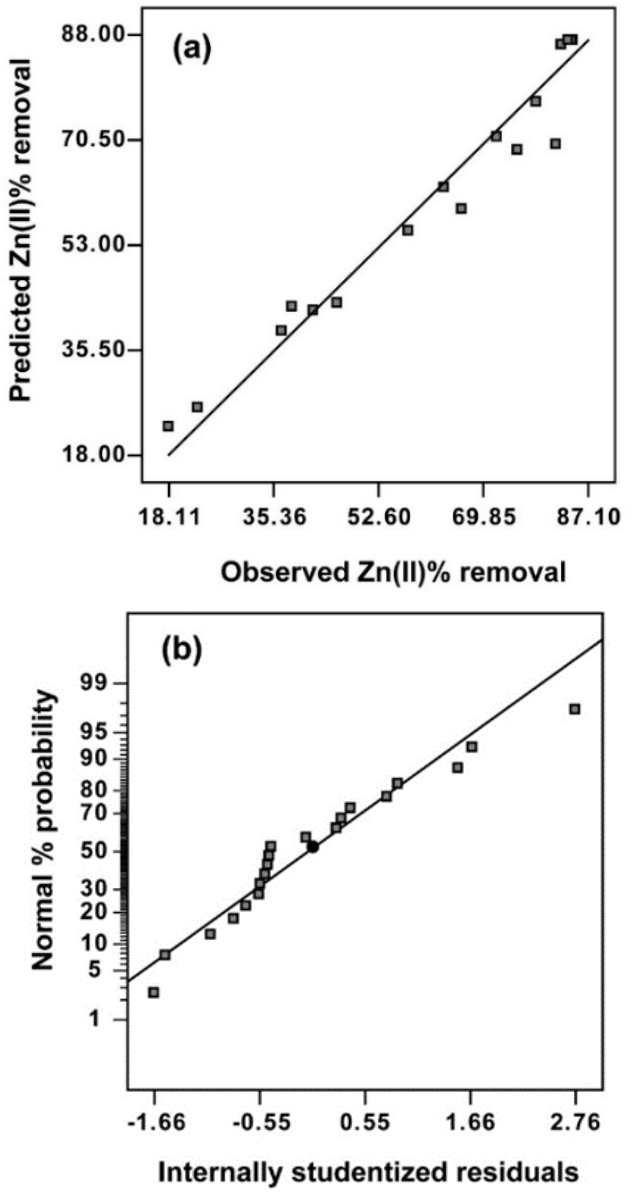

Figure 1. (a) Predicted versus observed values and (b) residual plots for $\mathrm{Zn}(\mathrm{II}) \%$ removal.

Figure $2 \mathrm{a}$ and $\mathrm{b}$ show the simultaneous effect of $\mathrm{pH}$ and $\mathrm{C}_{\mathrm{o}}$ on the removal efficiency of $\mathrm{Zn}(\mathrm{II})$ and the main effect of $\mathrm{pH}$ on the removal percentage of $\mathrm{Zn}(\mathrm{II})$, respectively. According to Figure 2a and b, increasing the $\mathrm{pH}$ of the solution from 2 to $\sim 6$ resulted in an increase in $\mathrm{Zn}(\mathrm{II}) \%$ removal. This is attributed to Pearson's Hard and Soft Acid-Base (HSAB) theory, indicating that $-\mathrm{SH}$ groups and $\mathrm{Zn}$ (II) ions have a strong bond for each other [13]. Moreover, the surface of MK is negatively charged at higher $\mathrm{pH}$ values. Therefore, the removal of $\mathrm{Zn}(\mathrm{II})$ gradually increases while $\mathrm{pH}$ increases due 
to electrostatic attraction between negatively-charged MK and $\mathrm{Zn}(\mathrm{II})$ ions [14]. When the $\mathrm{pH}$ was increased to the upper level of 6 , the removal rates for $\mathrm{Zn}$ (II) rapidly reduced. This can be explained by the $\mathrm{Zn}(\mathrm{OH})_{2}$ formation of $\mathrm{Zn}$ (II) ions [1, 7].
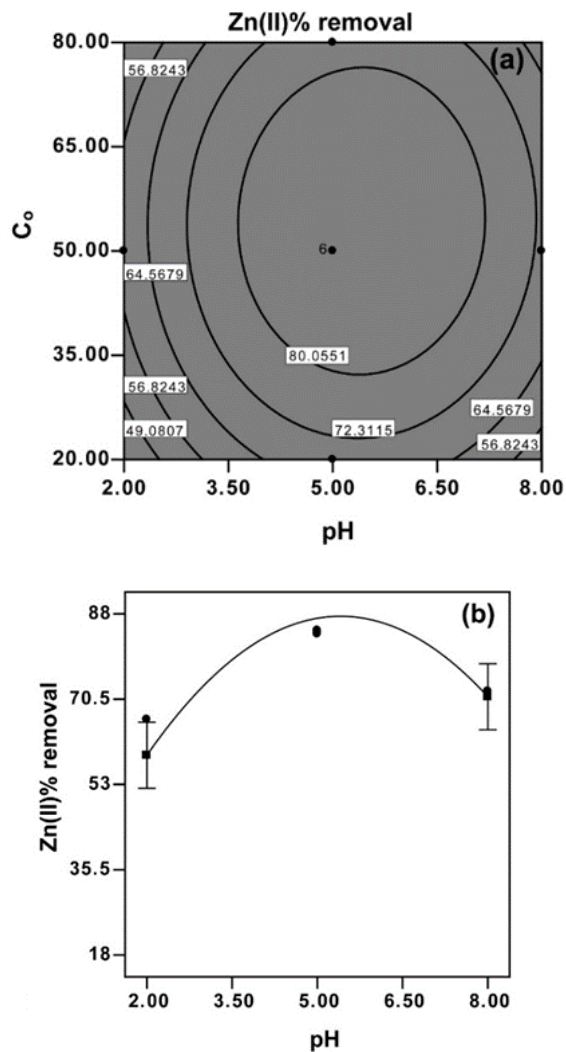

Figure 2. (a) Contour plot of $\mathrm{pH}$ and $\mathrm{Co}$, (b) the main effect plot of $\mathrm{pH}$ for $\mathrm{Zn}(\mathrm{II}) \%$ removal onto $\mathrm{MK}$.

Similarly, the contour plot of $\mathrm{C}_{0}$ and contact time and the main effect of $\mathrm{C}_{0}$ on $\mathrm{Zn}(\mathrm{II}) \%$ removal onto $\mathrm{MK}$ is shown in Figure $3 a$ and $b$, respectively. Analysis of the $C_{o}$ effect revealed that as $C_{0}$ increased in the ranges from 20 to 50 $\mathrm{mg} / \mathrm{L}$, the removal rate of $\mathrm{Zn}(\mathrm{II})$ increased; however, it decreased when $\mathrm{C}_{\mathrm{o}}$ was more than $50 \mathrm{mg} / \mathrm{L}$. The results imply that available binding sites for $\mathrm{Zn}(\mathrm{II}) \%$ removal were saturated with heavy metal ions and equilibrium was reached [14]. The correlation between the removal efficiency for $\mathrm{Zn}$ (II) ions and contact time vs $\mathrm{pH}$ and the main effect of contact time on $\mathrm{Zn}(\mathrm{II}) \%$ adsorption are given in Figure 4a and b, respectively. As can be understood from Figure $4 \mathrm{a}$ and b, $\mathrm{Zn}(\mathrm{II}) \%$ removal increased with an increase in contact time from 10 to $90-100$ min and did not change significantly with contact time after 90-100 min. This observation confirmed that an equilibrium state results at about 90-100 $\mathrm{min}$ for $\mathrm{Zn}(\mathrm{II}) \%$ removal [15].
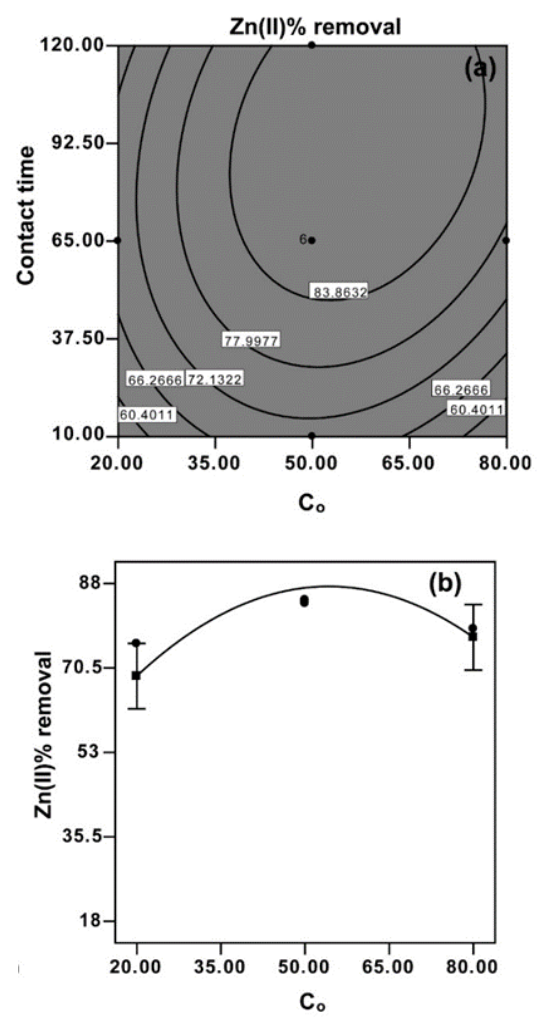

Figure 3. (a) Contour plot of $C_{o}$ and contact time, (b) the main effect plot of $C_{o}$ for $\mathrm{Zn}(\mathrm{II}) \%$ removal onto $M K$.
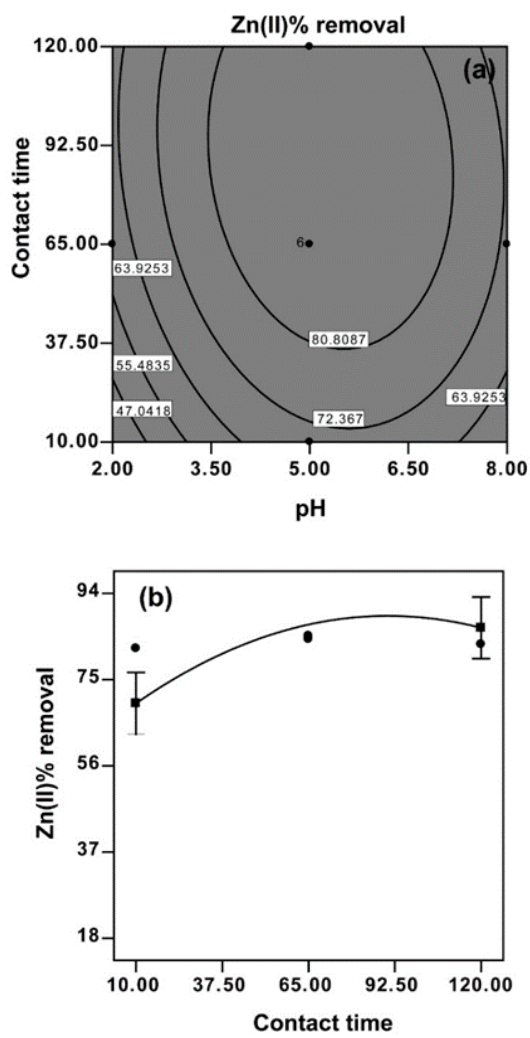

Figure 4. (a) Contour plot of $\mathrm{pH}$ and contact time, (b) the main effect plot of contact time for $\mathrm{Zn}(\mathrm{II}) \%$ removal onto $\mathrm{MK}$. 


\subsection{Numerical analysis results}

It is important to maximize the $\mathrm{Zn}(\mathrm{II})$ ion removal rate onto MK. This method utilized a quadratic model to maximize Zn(II)\% removal within the selected experimental range. The numerical analysis approach in CCD was used to determine the optimal points for Zn(II)\% removal onto MK. The optimal process points for $\mathrm{Zn}(\mathrm{II}) \%$ removal were found to be $\mathrm{pH}=$ $6.39, \mathrm{C}_{0}=50.09 \mathrm{mg} / \mathrm{L}$, and contact time $=76.10 \mathrm{~min}$. At these points, the maximum $\mathrm{Zn}(\mathrm{II}) \%$ removal was found as $86.19 \%$. Some tests were made to evaluate $\mathrm{Zn}(\mathrm{II}) \%$ removal at the obtained optimum adsorption points. The findings indicated that the removal percentage of $\mathrm{Zn}$ (II) onto MK is markedly increased compared to raw kaolin (49.15\%).

The maximum values for $\mathrm{Zn}(\mathrm{II})$ adsorption with different adsorbents are given in Table 3. These results indicated that the adsorption performance of MK are substantially good for $\mathrm{Zn}$ (II) adsorption and it is an ideal material for removal of $\mathrm{Zn}$ (II) from aqueous media.

\subsection{Adsorption mechanism}

MK was used as an adsorbent to remove $\mathrm{Zn}$ (II) ions from aqueous environments. The revelation of the possible mechanism has major significance to evaluate the nature of the process and show how MK as adsorbent interacts with $\mathrm{Zn}(\mathrm{II})$ as adsorbate. Figure 5 shows the proposed model for Zn(II)\% removal onto MK. During Zn(II) adsorption, Zn(II) ions first pass to the MK surface and reach the surface of MK by transfer from the boundary layer between the aqueous solution and MK. Subsequently, Zn(II) ions are affected by functional groups on MK. Then, Zn(II) ions are adsorbed onto MK. According to HSAB theory, there is strong interaction between thiol groups on the surface of MK and Zn(II) ions with each other [16]. Therefore, Zn-S bonding could be formed with $-\mathrm{SH}$ groups on the surface owing to the electrostatic interactions [17-19].

Moreover, the surface charge of the adsorbent is directly related to the solution $\mathrm{pH}$. At low $\mathrm{pH}$-values, the surface is positively charged and presence $\mathrm{H}^{+}$ions in the solution, leading to the decrease of $\mathrm{Zn}(\mathrm{II}) \%$ removal due to electrostatic repulsion between $\mathrm{Zn}(\mathrm{II})$ ions and positively charged adsorbent. On the other hand, an increase in $\mathrm{pH}$ of $\mathrm{Zn}$ (II) solution results in the reduction of positive surface charge, indicating that the electrostatic attraction between the negatively charged adsorbent surface and the positively charged $\mathrm{Zn}(\mathrm{II})$ ions. It is true that the predominant species of $\mathrm{Zn}(\mathrm{II})$ is $\mathrm{Zn}(\mathrm{OH})_{2}$ at $\mathrm{pH}>8$, corresponding that decrease in adsorption yield compared to neutral conditions [2, 20].
Table 3. A comparison of Zn(II) adsorption for previous studies in literature.

\begin{tabular}{|c|c|c|c|c|c|}
\hline Material & $\mathrm{C}_{0}(\mathrm{mg} / \mathrm{L})$ & $\begin{array}{c}\text { Ads. } \\
\text { Dosage } \\
\text { (g/50 mL) }\end{array}$ & $\underset{(\mathrm{mg} / \mathrm{g})}{\mathrm{q}_{\max }}$ & $\begin{array}{c}\mathrm{Zn}(\mathrm{II}) \\
\% \\
\text { removal }\end{array}$ & Ref. \\
\hline Seed pods & 50.13 & 0.15 & 13.04 & 78.02 & [14] \\
\hline $\begin{array}{l}\text { Palm kernel } \\
\text { shell based } \\
\text { activated } \\
\text { carbon }\end{array}$ & 55 & 0.55 & 4.29 & 85.82 & [3] \\
\hline $\begin{array}{l}\text { Oil palm } \\
\text { empty fruit } \\
\text { bunches }\end{array}$ & 200 & 0.4 & 15.18 & 25.49 & [21] \\
\hline $\begin{array}{l}\text { Maghemite } \\
\left(\gamma-\mathrm{Fe}_{2} \mathrm{O}_{3}\right)\end{array}$ & 50 & 0.24 & 4.79 & 45.41 & [5] \\
\hline $\begin{array}{l}\text { Modified } \\
\text { bentonite }\end{array}$ & $50-200$ & 0.5 & 35.21 & 43.88 & [22] \\
\hline $\begin{array}{l}\text { Gracilaria } \\
\text { Corticata }\end{array}$ & 100 & 1 & 4.75 & 95 & [12] \\
\hline MK & 50.09 & 0.25 & 8.64 & 86.19 & $\begin{array}{l}\text { This } \\
\text { work }\end{array}$ \\
\hline
\end{tabular}

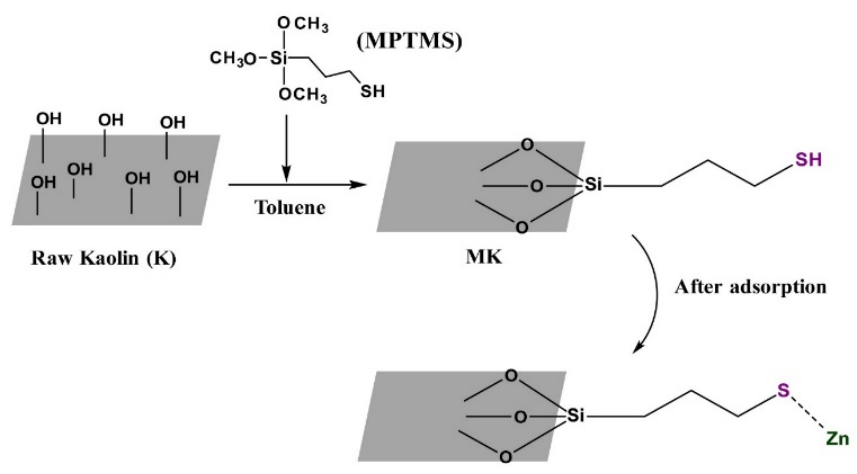

Figure 5. Possible adsorption mechanism for $\mathrm{Zn}(\mathrm{II})$ onto MK.

\section{Conclusions}

The influence of independent parameters such as $\mathrm{pH}, \mathrm{C}_{0}$, and contact time on the removal of $\mathrm{Zn}$ (II) from aqueous environments by MK was studied using CCD based on RSM. A quadratic model for $\mathrm{Zn}(\mathrm{II}) \%$ removal was developed using CCD, indicating that the obtained model fitted well to experimental values. ANOVA results showed that $p$-value is quite low $(<0.0001)$. It can be said that the quadratic model is sufficient to predict experimental data. From numerical analysis results, the maximum removal rate of $86.19 \%$ for $\mathrm{Zn}(\mathrm{II})$ by $\mathrm{MK}$ was found at $\mathrm{pH}$ of $6.39, \mathrm{C}_{0}$ of $50.09 \mathrm{mg} / \mathrm{L}$, and contact time of $76.10 \mathrm{~min}$. Consequently, the results suggest that MK has potential use as adsorbent for the removal of heavy metal ions such as Zn from aqueous environments. Moreover, it can be said that RSM is a promising approach to optimize and model the independent parameters affecting adsorption technology. 


\section{References}

[1]. Vojoudi H., Badiei A., Amiri A., Banaei A., Ziarani G.M., Schenk-Joß K., "Pre-concentration of Zn(II) ions from aqueous solutions using meso-porous pyridineenrobed magnetite nanostructures", Food Chemistry, 257, (2018), 189-195.

[2]. Mousavi S.J., Parvini M., Ghorbani M., "Experimental design data for the zinc ions adsorption based on mesoporous modified chitosan using central composite design method", Carbohydrate Polymers, 188, (2018), 197-212.

[3]. Karri R.R., Sahu J.N., "Modeling and optimization by particle swarm embedded neural network for adsorption of zinc (II) by palm kernel shell based activated carbon from aqueous environment", Journal of Environmental Management, 206, (2018), 178-191.

[4]. Shanmugaprakash M., Venkatachalam S., Rajendran K., Pugazhendhi A., "Biosorptive removal of Zn(II) ions by Pongamia oil cake (Pongamia pinnata) in batch and fixed-bed column studies using response surface methodology and artificial neural network", Journal of Environmental Management, 227, (2018), 216-228.

[5]. Ahmadi A., Heidarzadeh S., Mokhtari A.R., Darezereshki E., Harouni H.A., "Optimization of heavy metal removal from aqueous solutions by maghemite $(\gamma$ $\mathrm{Fe}_{2} \mathrm{O}_{3}$ ) nanoparticles using response surface methodology", Journal of Geochemical Exploration, 147, (2014), 151-158.

[6]. Yılmaz Ş., Zengin A., Şahan T., "A novel material poly(N-acryloyl-L-serine)-brush grafted kaolin for efficient elimination of malachite green dye from aqueous environments", Colloids and Surfaces A: Physicochemical and Engineering Aspects, 601, (2020), 125041.

[7]. Dev V.V., Baburaj G., Antony S., Arun V., Krishnan K.A., "Zwitterion-chitosan bed for the simultaneous immobilization of $\mathrm{Zn}(\mathrm{II}), \mathrm{Cd}(\mathrm{II}), \mathrm{Pb}(\mathrm{II})$ and $\mathrm{Cu}(\mathrm{II})$ from multi-metal aqueous systems", Journal of Cleaner Production, 255, (2020), 120309.

[8]. Corda N., Kini M.S., "Recent studies in adsorption of $\mathrm{Pb}(\mathrm{II}), \mathrm{Zn}(\mathrm{II})$ and $\mathrm{Co}(\mathrm{II})$ using conventional and modified materials:a review", Separation Science and Technology, 55, (2020), 2679-2698.

[9]. Olu-Owolabi B.I., Unuabonah E.I., "Adsorption of $\mathrm{Zn}^{2+}$ and $\mathrm{Cu}^{2+}$ onto sulphate and phosphate-modified bentonite", Applied Clay Science, 51, (2011), 170-173.

[10]. Jemima W.S., Magesan P., Chiranjeevi P., Umapathy M.J., "Sorption properties of organo modified montmorillonite clay for the reclamation of chromium (VI) from waste water", Silicon, 11, (2019), 925-933.
[11]. Bezerra M.A., Santelli R.E., Oliveira E.P., Villar L.S., Escaleira L.A., "Response surface methodology (RSM) as a tool for optimization in analytical chemistry", Talanta, 76, (2008), 965-977.

[12]. Assadian F., Niazi A., Ramezani M., "Response Surface Modeling and Optimization of Effective Parameters for Zn(II) Removal From Aqueous Solution Using Gracilaria Corticata", Journal of Chemical Health Risks, 10, (2020), 213-224.

[13]. Yılmaz Ş., Şahan T., Karabakan A., "Response surface approach for optimization of $\mathrm{Hg}$ (II) adsorption by 3mercaptopropyl trimethoxysilane-modified kaolin minerals from aqueous solution", Korean Journal of Chemical Engineering, 34, (2017), 2225-2235.

[14]. Liu X., Han B., Su C.-l., Han Q., Chen K.-j., Chen Z.-q., "Optimization and mechanisms of biosorption process of $\mathrm{Zn}(\mathrm{II})$ on rape straw powders in aqueous solution", Environmental Science and Pollution Research, 26, (2019), 32151-32164.

[15]. Biswas S., Bal M., Behera S.K., Sen T.K., Meikap B.C., "Process optimization study of $\mathrm{Zn}^{2+}$ adsorption on biochar-alginate composite adsorbent by response surface methodology (RSM)", Water, 11, (2019), 325.

[16]. Košak A., Lobnik A., Bauman M., "Adsorption of mercury(II), lead(II), cadmium(II) and zinc(II) from aqueous solutions using mercapto-modified silica particles", International Journal of Applied Ceramic Technology, 12, (2015), 461-472.

[17]. Hao J., Han M.-J., Wang C., Meng X., "Enhanced removal of arsenite from water by a mesoporous hybrid material - Thiol-functionalized silica coated activated alumina", Microporous and Mesoporous Materials, 124, (2009), 1-7.

[18]. Li G., Zhao Z., Liu J., Jiang G., "Effective heavy metal removal from aqueous systems by thiol functionalized magnetic mesoporous silica", Journal of Hazardous Materials, 192, (2011), 277-283.

[19]. Mirzaee S.S., Salahi E., Khanlarkhani A., "Kinetics, isotherms and thermodynamic modeling of $\mathrm{Mn}^{2+}$ and $\mathrm{Zn}^{2+}$ single and binary removal using mercapto functionalized silica aerogel", Journal of Dispersion Science and Technology, 40, (2019), 657-667.

[20]. Rodríguez C.A., Sandoval-Paz M.G., Saavedra R., Trejo-Cruz C., De la Carrera F., Aragon L.E., Sirena M., Delplancke M.-P., Carrasco C., "Comprehensive study of growth mechanism and properties of low $\mathrm{Zn}$ content Cd1-xZnxS thin films by chemical bath", Materials Research, 19, (2016), 1335-1343.

[21]. Zamani S.A., Yunus R., Samsuri A.W., Salleh M.A.M., Asady B., "Removal of zinc from aqueous solution by optimized oil palm empty fruit bunches biochar as low 
cost adsorbent", Bioinorganic Chemistry and Applications, 2017, (2017), 7914714.

[22]. Tohdee K., Kaewsichan L., Asadullah, "Enhancement of adsorption efficiency of heavy metal $\mathrm{Cu}(\mathrm{II})$ and $\mathrm{Zn}(\mathrm{II})$ onto cationic surfactant modified bentonite", Journal of Environmental Chemical Engineering, 6, (2018), 28212828. 